\title{
DETECTION OF AEROMONAS HYDROPHILA IN RAW MILK AND SOME MILK PRODUCTS WITH REFERENCE TO ITS PUBLIC HEALTH HAZARD
}

\author{
O.A. SADEK ${ }^{1}$, N.H. MAKAR ${ }^{2}$ and S.M. EL BERBAWY ${ }^{2}$ \\ ${ }^{1}$ Food Hygiene Department, Animal Health Research Institute, Assiut Lab. \\ ${ }^{2}$ Bacteriology Department, Animal Health Research Institute, Assiut Lab.
}

Received: 31 January 2017; Accepted: 22 February 2017

\begin{abstract}
This study aimed to determine Aeromonas spp. in raw milk and some milk products. A total of 100 raw milk, kareish cheese, ice cream and baladi yoghurt (25 samples, each) were collected from different dairy shops and street peddlers in Assiut city, Egypt and were bacteriologically examined for presence and count of Aeromonas spp. The incidences of counted Aeromonas spp. in raw milk, kareish cheese, ice cream and baladi yoghurt were $36,32,24$ and $0.0 \%$, respectively, with average counts of $1.0 \times 10^{5}, 3.2 \times 10^{4}, 5.0 \times 10^{2}$ and $<100 \mathrm{cfu} / \mathrm{ml}$, respectively. The incidences of counted Aeromonas hydrophila, in raw milk, kareish cheese and ice cream were 16, 12 and 8\%, while for Aeromonas caviae, the incidences were 12, 16 and 12\%, respectively. Moreover, the incidences of counted Aeromonas sobria in raw milk, kareish cheese and ice cream were 8, 4 and 4\%, respectively. Baladi yoghurt samples were negative for Aeromonas spp. in this study. All the recovered Aeromonas hydrophila organisms were confirmed by PCR assay for the presence of $16 S$ rRNA gene and $100 \%$ of the tested strains harboured this gene. The aerA and ahh1 virulence genes were present in Aeromonas hydrophila in percentages of 66.67 and $77.78 \%$, respectively. All the recovered Aeromonas hydrophila, Aeromonas caviae and Aeromonas sobria strains, in this study, exhibited $100 \%$ virulence properties on bases of proteolytic, lioplytic, psychrotrophic and $\beta$-haemolytic activities. The recovered Aeromonas hydrophila, Aeromonas caviae and Aeromonas sobria exhibited 100\% resistance towards Ampicillin, Amoxicillin and Erythromycin antibiotics, while, they exhibited $100 \%$ sensitivity towards Ciprofloxacin. The public health hazards of occurrence of Aeromonas spp. in milk and its products as well as the suggestive control measures were discussed.
\end{abstract}

Key words: Aeromonas hydrophila, Raw Milk, Public Health Hazard

\section{INTRODUCTION}

Milk is an excellent medium for the growth of numerous microbes which produce consequential spoilage of the milk and various milk products or food-borne pathogens to the consumers (Oliver et al., 2005). Aeromonads are autochthonous to the aquatic environment (Aboulhamd, 2010) and are also common contaminants in diverse variety of foods like fish, sea foods, raw and cooked meats, poultry, milk and milk products, eggs and vegetables (Sharma and Kumar 2011). Scoaris et al. (2008) showed that, Aeromonads are efficient colonizers of surfaces and are an important constituent of bacterial biofilms in both water distribution systems and food processing environments.

Corresponding author: Dr.O.A. SADEK E-mail address:onsi_2000@yahoo.com

Present address:Food Hygiene Department, Animal Health Research Institute, Assiut Lab
Isolation of Aeromonas hydrophila from water and food sources, and the increasing resistance of this organism to antibiotics and chlorination in water, presents a significant threat to public health (Chang et al., 2008). Also, Aeromonas species have also been linked to both food and water-borne diseases in different parts of the world especially developing countries due to poor personal hygiene and lack of quality water (Odeyemi and Ahmad, 2014). Moreover, Aeromonas hydrophila and Aeromonas caviae are considered major pathogens most commonly implicated in human intestinal infections (Van Gravenitz, 2007) and also account for more than 95\% of all blood-borne infections (Ghenghesh et al., 2008). Furthermore, Five types of diarrhea of Aeromonas related gastroenteritis, secretory (acute watery diarrhea often with vomiting), dysenteric (accompanied by blood and mucus in the stool), chronic (lasting longer than 10 days), choleric (rice water stools) and travelers were reported (Janda and Duffey, 1988).

Extra-intestinal infections due to Aeromonas species as fatal bacteremic pneumonia, orbital cellulitis, fatal Aeromonas hydrophila infection of soft tissue in a 
cirrhotic patient, epidural abscess, wound infection, prostatitis, septic shock, ecthyma gangrenosum, diabetic foot, fatal Aeromonas hydrophila myonecrosis and sepsis were reported (Kao et al., 2003; Chou et al., 2004; Liu et al., 2005; Tsai et al., 2005; Easow and Tuladhar, 2007; Avolio et al., 2009; Talan et al., 2014 and Yumoto et al., 2014).

It has been observed that some strains of Aeromonas are enteropathogenic and possess virulence factors as enterotoxins, cytotoxins, haemolysins and invasins and this association between haemolysin production and enterotoxicity is none other than the Aeromonas sp. which can grow and release enterotoxin and haemolysin even at fridge temperature conditions (Sharma and Kumar, 2012). Antimicrobial resistance among enteric pathogens is a serious problem in developing countries where there is a high frequency of gastroenteric illness and many antibiotics fall routinely into inadequate use. Antibiotic resistance is particularly relevant in pathogenic Aeromonas species in which, besides the classical resistance to $\beta$ lactamic antibiotics, multiple-resistance has been frequently identified (Vila et al., 2002). These bacteria can receive and transfer antibiotic resistance genes to other Gram negative bacteria (Marchandin et al., 2003).

Due to the public health hazard of Aeromonas species, this study aimed to detect these microorganisms in raw milk and some milk products consumed in Assiut city, Egypt. Also, to determine the antimicrobial resistance, proteolytic, lioplytic, psychrotrophic and haemolytic activities of the isolated organisms. Moreover, confirmation of Aeromonas hydrophila strains by detection of $16 \mathrm{~S}$ rRNA gene and determination of haemolysin (ahh1) and aerolysin (aerA) virulence genes of isolated strains by PCR assay were assessed.

\section{MATERIALS AND METHODS}

A total of 100 raw milk, kareish cheese (traditional Egyptian cheese made from raw skimmed milk), ice cream and baladi yoghurt (25 samples, each) were collected from dairies and street peddlers in Assiut city, Egypt. The samples were collected in clean and sterile plastic bags in an ice-box and transferred rapidly as soon as possible to the laboratory for bacteriological examination.

\section{A) Preparation of samples:}

The apparently normal raw milk samples were mixed thoroughly and tested for heat treatment by Storch test according to Lampert (1975) before being subjected to examination. Ten $\mathrm{ml}$ from liquid samples and $10 \mathrm{~g}$ from solid samples were added individually to $90 \mathrm{ml}$ of $0.1 \%$ sterile peptone water. Ten-fold serial dilutions from each sample were done up to $10^{6}$ (A.P.H.A., 2001).

B) Bacteriological examination of the prepared samples:

1) Enumeration of Aeromonas hydrophila, using m-Aeromonas selective agar, according to Palumbo et al. (2001): From each dilutions, 0.1 $\mathrm{ml}$ was spread over m-Aeromonas selective agar containing $10 \mathrm{mg}$ ampicillin/liter with sterile bent glass rod and incubated at $28{ }^{\circ} \mathrm{C}$ for 24 hours. Then the numbers of isolated Aeromonas were calculated and typical colonies were picked into nutrient agar slants for biochemical identification.

2) Application of PCR for identification of $16 \mathrm{~S}$ rRNA, aerolysin (aerA) and haemolysin (ahh1) virulence genes of Aeromonas hydrophila:-

a) Primer sequences of Aeromonas hydrophila used for PCR identification system: Application of PCR for identification of $16 \mathrm{~S}$ rRNA, aerolysin (aerA) and haemolysin (ahh1) virulence genes of Aeromonas hydrophila was performed essentially by using primers (Pharmacia Biotech) as shown in the following table:

\begin{tabular}{|c|c|c|c|c|}
\hline Target genes & Primers & Oligonucleotide sequence $\left(5^{\prime} \rightarrow 3^{\prime}\right)$ & Product size (bp) & Reference \\
\hline \multirow{2}{*}{$16 S$ rRNA } & AHH1 (F) & 5' GGGAGTGCCTTCGGGAATCAGA '3 & \multirow{2}{*}{356} & \multirow{6}{*}{$\begin{array}{l}\text { Stratev et } \\
\text { al. (2016) }\end{array}$} \\
\hline & AHH1 (R) & 5' TCACCGCAACATTCTGATTTG '3 & & \\
\hline \multirow{2}{*}{$\operatorname{aer} \mathrm{A}$} & AH-aerA (F) & 5' CAAGAACAAGTTCAAGTGGCCA '3 & \multirow{2}{*}{309} & \\
\hline & AH-aerA (R) & 5' ACGAAGGTGTGGTTCCAGT '3 & & \\
\hline \multirow[b]{2}{*}{$\operatorname{ahh} 1$} & A16S (F) & 5' GCCGAGCGCCCAGAAGGTGAGTT'3 & \multirow{2}{*}{130} & \\
\hline & $\mathrm{A} 16 \mathrm{~S}(\mathrm{R})$ & 5' GAGCGGCTGGATGCGGTTGT '3 & & \\
\hline
\end{tabular}


b) DNA Extraction using QIA amp kit (Shah et al., 2009): After sub-culturing of Aeromonas hydrophila on starch ampicilin agar, one or two colonies were suspended in $20 \mathrm{ml}$ of sterile distilled water, and the suspension was then heated at $100{ }^{\circ} \mathrm{C}$ for 20 minutes. Accurately, DNA was extracted from all isolates by using QIAamp kit (Qiagen, Hilden, Germany) according to the manufacturer's instructions). All DNA extracts were stored at $-20^{\circ} \mathrm{C}$ until used.

c) Amplification reaction of Aeromonas hydrophila (Wang et al., 2003): The amplification was performed on a Thermal Cycler (Master cycler, Eppendorf, Hamburg, Germany). Multiplex PCR assays were adopted by using $25 \mu \mathrm{l}$ of the reaction mixture contained 2X AmpliTaq DNA polymerase (Perkin-Elmer) - $12.5 \mu \mathrm{l}$, and $1.0 \mu \mathrm{l}$ of each ahhl and aerA primers, $0.2 \mu \mathrm{l}$ of $16 \mathrm{~S}$ rRNA primers and $1 \mu \mathrm{l}$ extracted DNA. Amplification conditions consisted of an initial denaturation at $95{ }^{\circ} \mathrm{C}$ for 5 min., 50 cycles at $95{ }^{\circ} \mathrm{C}$ for $30 \mathrm{sec}$., $59^{\circ} \mathrm{C}$ for 30 sec., $72^{\circ} \mathrm{C}$ for $30 \mathrm{sec}$., followed by final elongation at $72^{\circ} \mathrm{C}$ for $7 \mathrm{~min}$. Amplified DNA fragments were analyzed by $2 \%$ of agarose gel electrophoresis (Applichem, Germany, GmbH) in 1X TAE buffer (0.04 M Tris, $0.02 \mathrm{M}$ Acetic acid, $0.002 \mathrm{M} \mathrm{Na} 2 \mathrm{EDTA}$ ) at $100 \mathrm{~V}$ for $45 \mathrm{~min}$ with 8 $\mu \mathrm{l}$ PCR product. Finally, the gel was stained with ethidium bromide and captured as well as visualized on UV transilluminator. A $100 \mathrm{bp}$ plus DNA Ladder (Qiagen, Germany, GmbH) was used to determine the fragment sizes.

3) Detection of proteolytic activity of Aeromonas spp. according Swift et al. (1999): This was performed by placing aseptically loopful of culture on the center of the $10 \%$ of skim milk agar plate and spreading it in a circular fashion to cover an area about 5 to $18 \mathrm{~mm}$ in diameter; then the plates were incubated in an inverted position at $37^{\circ} \mathrm{C}$ for 24 to $48 \mathrm{~h}$. Clearing the cloudy agar (zone of proteolysis) indicated a positive result.
4) Detection of lipolytic activity of Aeromonas spp. according to Harrigan (1998): The strains were subcultured in tributyrin agar (Plate Count Agar supplemented with $1 \%$ tributyrin) and then incubated at $37{ }^{\circ} \mathrm{C}$ for $48 \mathrm{~h}$. The colonies were considered positive when a precipitation halo formed around the colony, indicating the release of enzymes into the growth medium.

5) Determination of psychrotrophic activity of Aeromonas spp., using Standard Plate count Agar, according to A.P.H.A. (2001): The isolated Aeromonas spp. strains were inoculated on Standard Plate Count Agar and incubated at 7 ${ }^{\circ} \mathrm{C}$ for 10 days then examined for Aeromonas growth.

6) Determination of haemolytic activity of Aeromonas spp. according to Swift et al. (1999): Haemolytic positive isolates were identified by the presence of clear ( $\beta$-haemolysis) halos around the colonies grown at $37{ }^{\circ} \mathrm{C}$ for 24 $\mathrm{h}$ on TSA agar (Difco) containing $5 \%$ rabbit blood.

7) Antibiogram of Aeromonas species according to CLSI (2011): Aeromonas spp. strains isolated in the present study were subjected to susceptibility testing against 8 antimicrobials commonly used. Susceptibility was determined by the disk-diffusion technique of Kirby-Bauer on Mueller-Hinton agar plates with inocula adjusted to an optical density of 0.5 McFarland standard units. Disks containing Ampicillin

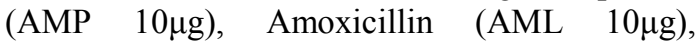

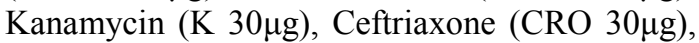

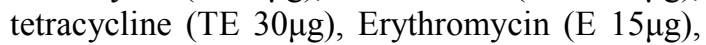
Trimethoprim/Sulfamethoxazole (SXT 25 $\mu \mathrm{g}$ ) and ciprofloxacin (CIP 5 $\mu \mathrm{g}$ ) were used. After $24 \mathrm{~h}$ incubation at $30^{\circ} \mathrm{C}$, organisms were classified as Sensitive (S), Intermediately resistant (I) or Resistant (R) on the basis of the size of the zone of bacteria growth inhibition.

\section{RESULTS}

Table 1: Aeromonas spp. count in raw milk, kareish cheese, ice-cream and yoghurt $(\mathrm{n}=25)$.

\begin{tabular}{|c|c|c|c|c|c|c|}
\hline \multirow{3}{*}{ Type of sample } & \multicolumn{6}{|c|}{ Aeromonas spp. count $(\mathrm{cfu} / \mathrm{ml}$ or cfu/g) } \\
\hline & \multicolumn{2}{|c|}{ Positive countable samples } & \multirow{2}{*}{ Min. } & \multirow{2}{*}{ Max. } & \multirow{2}{*}{ Average } & \multirow{2}{*}{$\pm \mathrm{SE}$} \\
\hline & No. & $\%$ & & & & \\
\hline Raw milk & 9 & 36 & $<100$ & $1.2 \times 10^{6}$ & $1.0 \times 10^{5}$ & $5.6 \times 10^{4}$ \\
\hline Kareish cheese & 8 & 32 & $<100$ & $6.0 \times 10^{5}$ & $3.2 \times 10^{4}$ & $2.4 \times 10^{4}$ \\
\hline Ice cream & 6 & 24 & $<100$ & $7.0 \times 10^{3}$ & $5.0 \times 10^{2}$ & $2.9 \times 10^{2}$ \\
\hline Baladi yoghurt & - & 0.0 & $<100$ & $<100$ & $<100$ & - \\
\hline
\end{tabular}

$<100$ means negative samples 
Table 2: Incidence of countable Aeromonas spp. in raw milk, kariesh cheese and ice-cream samples $(\mathrm{n}=25)$.

\begin{tabular}{ccccccc}
\hline & \multicolumn{5}{c}{ Positive results } \\
\cline { 2 - 6 } Type of sample & \multicolumn{7}{c}{ Aeromonas hydrophila } & Aeromonas caviae & Aeromonas sobria \\
\cline { 2 - 7 } & No. & $\%$ & No. & $\%$ & No. & $\%$ \\
\hline Raw milk & 4 & 16 & 3 & 12 & 2 & 8 \\
\hline Kareish cheese & 3 & 12 & 4 & 16 & 1 & 4 \\
\hline Ice-cream & 2 & 8 & 3 & 12 & 1 & 4 \\
\hline
\end{tabular}

Table 3: Proteolytic and lipolytic activities of Aeromonas spp. detected in raw milk, kareish cheese and icecream samples.

\begin{tabular}{|c|c|c|c|c|c|}
\hline \multirow{3}{*}{ Tested organisms } & \multirow{3}{*}{$\begin{array}{l}\text { No. of tested } \\
\text { isolates }\end{array}$} & \multirow{2}{*}{\multicolumn{2}{|c|}{$\frac{\text { Proteolytic activity }}{\text { Positive samples }}$}} & \multirow{2}{*}{\multicolumn{2}{|c|}{$\begin{array}{c}\text { Lipolytic activity } \\
\text { Positive samples }\end{array}$}} \\
\hline & & & & & \\
\hline & & No. & $\%$ & No. & $\%$ \\
\hline Aeromonas hydrophila & 9 & 9 & 100 & 9 & 100 \\
\hline Aeromonas caviae & 10 & 10 & 100 & 10 & 100 \\
\hline Aeromonas sobria & 4 & 4 & 100 & 4 & 100 \\
\hline
\end{tabular}

Table 4: Psychrotrophic and haemolytic activities of Aeromonas spp. detected in raw milk, kareish cheese and ice-cream samples.

\begin{tabular}{|c|c|c|c|c|c|}
\hline \multirow{3}{*}{ Tested organisms } & \multirow{3}{*}{$\begin{array}{l}\text { No. of tested } \\
\text { isolates }\end{array}$} & \multicolumn{2}{|c|}{ Psychrotrophic activity } & \multicolumn{2}{|c|}{$\beta$-haemolysis } \\
\hline & & \multicolumn{2}{|c|}{ Positive samples } & \multicolumn{2}{|c|}{ Positive samples } \\
\hline & & No. & $\%$ & No. & $\%$ \\
\hline Aeromonas hydrophila & 9 & 9 & 100 & 9 & 100 \\
\hline Aeromonas caviae & 10 & 10 & 100 & 10 & 100 \\
\hline Aeromonas sobria & 4 & 4 & 100 & 4 & 100 \\
\hline
\end{tabular}

Table 5: Incidence of $16 \mathrm{~S}$ rRNA, aerolysin (aerA) and haemolysin (ahh1) virulence genes in isolated Aeromonas hydrophila organism $(\mathrm{n}=9)$.

\begin{tabular}{|c|c|c|c|c|c|c|}
\hline \multirow{3}{*}{ Tested organisms } & \multirow{2}{*}{\multicolumn{2}{|c|}{$\begin{array}{c}16 S \text { rRNA gene } \\
\text { Positive }\end{array}$}} & \multicolumn{2}{|c|}{ Aerolysin $(\operatorname{aer} \mathrm{A})$ gene } & \multicolumn{2}{|c|}{ Haemolysin $(a h h 1)$ gene } \\
\hline & & & \multicolumn{2}{|c|}{ Positive } & \multicolumn{2}{|c|}{ Positive } \\
\hline & No. & $\%$ & No. & $\%$ & No. & $\%$ \\
\hline Aeromonas hydrophila & 9 & 100 & 6 & 66.67 & 7 & 77.78 \\
\hline
\end{tabular}




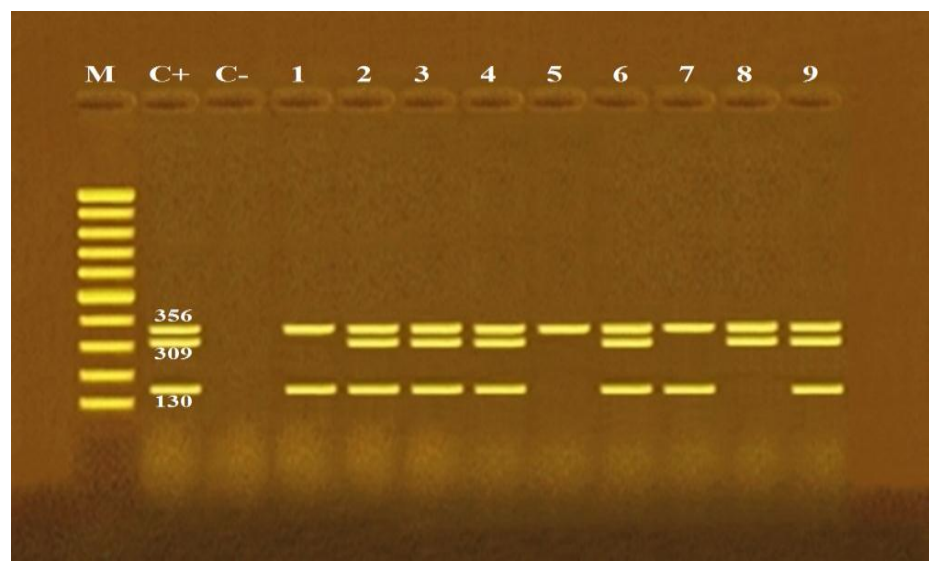

Photograph (1): Agarose gel electrophoresis of multiplex PCR of 165 rRNA (356 bp), aerA (309 bp) and ahhl $(130 \mathrm{bp})$ genes for characterization of Aeromonas hydrophila.

Lane M: 100 bp ladder as molecular size DNA marker.

Lane C+: Control positive Aeromonas hydrophila for $16 S \mathrm{rRNA}$, aerA and ahhl genes.

Lane C-: Control negative.

Lanes 2, 3, 4, 6 \& 9: Positive Aeromonas hydrophila for $16 S$ rRNA, aerA and ahhl genes.

Lanes 1 \& 7: Positive Aeromonas hydrophila strains for $16 \mathrm{~S}$ rRNA and ahhl genes.

Lane 8: Positive Aeromonas hydrophila strain for $16 S$ rRNA and aerA genes.

Lane 5: Positive Aeromonas hydrophila strain for $16 S$ rRNA gene.

Table 6: Antibiogram of Aeromonas spp. isolated from raw milk and some milk products.

\begin{tabular}{|c|c|c|c|c|c|c|c|c|c|c|c|c|c|c|c|c|c|c|}
\hline \multirow{3}{*}{ Antibiotics } & \multicolumn{6}{|c|}{ Aeromonas hydrophila $(\mathrm{n}=9)$} & \multicolumn{6}{|c|}{ Aeromonas caviae $(\mathrm{n}=10)$} & \multicolumn{6}{|c|}{ Aeromonas sobria $(n=4)$} \\
\hline & \multicolumn{2}{|c|}{ Sensitive } & \multicolumn{2}{|c|}{ Intermediate } & \multicolumn{2}{|c|}{ Resist } & \multicolumn{2}{|c|}{ Sensitive } & \multicolumn{2}{|c|}{ Intermediate } & \multicolumn{2}{|c|}{ Resist } & \multicolumn{2}{|c|}{ Sensitive } & \multicolumn{2}{|c|}{ Intermediate } & \multicolumn{2}{|c|}{ Resist } \\
\hline & No. & $\%$ & No. & $\%$ & No. & $\%$ & No. & $\%$ & No. & $\%$ & No. & $\%$ & No. & $\%$ & No. & $\%$ & No. & $\%$ \\
\hline Ampicillin & - & 0.0 & - & 0.0 & 9 & 100 & - & 0.0 & - & 0.0 & 10 & 100 & - & 0.0 & - & 0.0 & 4 & 100 \\
\hline Amoxicillin & - & 0.0 & - & 0.0 & 9 & 100 & - & 0.0 & - & 0.0 & 10 & 100 & - & 0.0 & - & 0.0 & 4 & 100 \\
\hline Kanamycin & 2 & 22.22 & 3 & 33.33 & 4 & 44.44 & 4 & 40 & 5 & 50 & 1 & 10 & 3 & 75 & 1 & 25 & - & 0.0 \\
\hline Ceftriaxone & 5 & 55.56 & 1 & 11.11 & 3 & 33.33 & 4 & 40 & 3 & 30 & 3 & 30 & 3 & 75 & 1 & 25 & - & 0.0 \\
\hline Tetracycline & 4 & 44.44 & 1 & 11.11 & 4 & 44.44 & 5 & 50 & - & 0.0 & 5 & 50 & 1 & 25 & 1 & 25 & 2 & 50 \\
\hline Erythromycin & - & 0.0 & - & 0.0 & 9 & 100 & - & 0.0 & - & 0.0 & 10 & 100 & - & 0.0 & - & 0.0 & 4 & 100 \\
\hline $\mathrm{TSX}^{*}$ & - & 0.0 & 2 & 22.22 & 7 & 77.78 & 2 & 20 & 3 & 30 & 5 & 50 & 2 & 50 & 2 & 50 & - & 0.0 \\
\hline Ciprofloxacin & 9 & 100 & - & 0.0 & - & 0.0 & 10 & 100 & - & 0.0 & - & 0.0 & 4 & 100 & - & 0.0 & - & 100 \\
\hline
\end{tabular}

*Trimethoprim-Sulfamethoxazole

\section{DISCUSSION}

The illustrated results in Table 1 revealed that, the incidence of counted Aeromonas spp. in the examined raw milk samples was $36 \%$, with counts ranging from $<100$ to $1.2 \times 10^{6}$ and with an average count of $1.0 \times 10^{5} \mathrm{cfu} / \mathrm{ml}$. Lower incidences $(8.7,26$ and 32\%) were estimated by Amer et al. (2008); Enany et al. (2013) and Ahmed et al. (2014), respectively. On the other hand, higher incidences (40, 49.2, 86.7, 46.7 and $58 \%$ ) were detected by El-Shorbagy and AlGanzoury (2002); Yucel et al. (2005); Korashy (2006); El-Taib and Mohamed (2010) and Eid et al. (2013), respectively. It is worth mentioning that, Aeromonas organisms can invade udder tissues; multiply in mammary tissues and subsequently discharge in milk. Also, the contaminated water used for washing milking equipments is considered as a significant source of contamination. Therefore, presence of Aeromonas in a high level in raw milk samples in this study is indicative to bad hygienic measures of milk production and distribution (Korashy, 2006).

The incidence of counted Aeromonas spp. in the examined kareish cheese samples was $32 \%$, with a count ranging from $<100$ to $6.0 \times 10^{5}$ and with an average count of $3.2 \times 10^{4} \mathrm{cfu} / \mathrm{g}$ (Table 1). Lower incidence of $12 \%$ was reported by Enany et al. (2013), whereas, higher incidences (92, 58, 70 and 
$70 \%$ ) were revealed by Al-Ashmawy (2000); Effat et al. (2000); Korashy (2006) and Eid et al. (2013), respectively. The presence of Aeromonas species in kareish cheese could be attributed to the bad quality of the raw milk used, the unsanitary manufacturing practices, improper handling and distribution. Also, the kareish cheese manufacturing process itself does not appear to be deleterious to Aeromonas spp.

Moreover, the incidence of counted Aeromonas spp. in ice cream samples was $24 \%$, with a count ranging from $<100$ to $7.0 \times 10^{3}$ and with an average count of $5.0 \times 10^{2} \mathrm{cfu} / \mathrm{g}$ (Table 1). Lower incidence of $18 \%$ was estimated by Sharef et al. (2006). The presence of Aeromonas spp. in ice cream samples indicated the unhygienic measures during preparation and distribution of the products. Aeromonas spp. isolated from human stool samples in percentage of $3.4 \%$ (Aslani and Alikhani, 2004), therefore, presence of Aeromonas hydrophila in ice cream may indicate faecal contamination from workers. Furthermore, good hygienic practices and good personal hygiene must be applied to produce products save for human consumption.

Aeromonassp. was not detected in baladi yoghurt samples in this study (Table 1). Motlagh et al. (1991) reported that, starter culture bacteria in yoghurt can produce antimicrobial activity against Aeromonas hydrophila and they declared that, diacetyl had some bactericidal activity against the tested strains. This observation could explain why Aeromonas was not detected in yoghurt samples in this study. Moreover, low $\mathrm{pH}$ of yoghurt may have an inhibitory effect on Aeromonas organisms or other factors which need further investigation.

The incidence of Aeromonas hydrophila in the examined raw milk samples was $16 \%$ (Table 2). Similar incidences (15.9 and 17.1\%) were found by Melas et al. (1999) and Subashkumar et al. (2006), respectively. Whereas, lower incidences (9 and 7\%) were detected by El-Leboudy et al. (2014) and Alrazakkazal and Abdullah (2016), respectively. On the other hand, higher incidences (36 and 24\%) were revealed by Abdel-Raouf and Naima (2011) and Zeinhom and Abdel-Latef (2014), respectively. Aeromonas hydrophila isolated from feaces of normal cow in percentage of $21.1 \%$ (Agarwal et al., 2000), therefore, presence of Aeromonas hydrophila in raw milk may indicate faecal contamination of milk.

Table 2 revealed that, the incidence of Aeromonas hydrophila in the examined kareish cheese samples was $12 \%$. Higher incidence of $32.5 \%$ was obtained by Nazem et al. (2010). While for the examined ice cream samples, the incidence of Aeromonas hydrophila was $8 \%$. Higher incidence of $40 \%$ was estimated by Nazem et al. (2010). From the aforementioned results, raw milk, kareish cheese and ice cream may cause risks for public health from Aeromonas hydrophila infection, especially for immune-compromised person, children and aged. Hence, there is need for public enlightenment, campaign and general education to assist in curtailing the outbreak of diseases in human through ingestion of the bacteria along with milk and milk products. Preventive method should be taken during food preparation; good personal hygiene and proper sanitation procedure should always be use to prevent human exposure to this disease.

The entire isolated Aeromonas hydrophila organism detected in raw milk, kareish cheese and ice cream $(9$ strains), in this study, were confirmed by PCR assay for detection of $16 \mathrm{~S}$ rRNA gene and all the tested isolate were harboring this gene (Table 5 and Photograph 1). The $16 S$ rRNA gene was included as an internal control and has become the gold standard method for definitive species identification (Wang et al., 2003 and Geetha and Michael, 2015).

Aeromonas caviae was isolated from raw milk samples in percentage of $12 \%$ (Table 2). Similar incidence of $13 \%$ was revealed by Melas et al. (1999). For kareish cheese samples, the incidence of Aeromonas caviae was $16 \%$ (Table 2) and this result was lower than that detected by Effat et al. (2000). Concerning ice cream samples, the incidence of Aeromonas caviae was $12 \%$ (Table 2).

The incidence of Aeromonas sobria in the examined raw milk samples was $8 \%$ (Table 2). Lower result (3.6\%) was obtained by Melas et al. (1999), whereas higher incidence was estimated by Akan et al. (1996). In contrary, Seker et al. (2015) could not isolate the organism from milk samples. Regarding to kareish cheese samples, the incidence of Aeromonas sobria was $4 \%$ (Table 2). Higher incidences were detected by Effat et al. (2000) and Korashy (2006). With regard to ice cream samples, the incidence of Aeromonas sobria was $4 \%$ (Table 2). The aforementioned results revealed that, Aeromonas hydrophila and Aeromonas caviae organisms were the most predominant strains isolated from raw milk, kareish cheese and ice cream samples followed by Aeromonas sobria.

The isolated Aeromonas hydrophila, Aeromonas caviae and Aeromonas sobria organisms in this study were tested for its virulence properties by proteolytic and lipolytic assay and all the tested isolates exhibited $100 \%$ proteolytic and lipolytic activities (Table 3). Similar results were observed by Castro-Escarpulli et al. (2003), Singh et al. (2010), Al-Fathawy and AlAmmar (2013), Al-Oqaili et al. (2016) and Simon et al. (2016).

It is worth mentioning that, Proteases play an important role in gastroenteritis by proteolytic 
activation of the haemolysin and also, it plays an important role in pathogenesis by providing nutrients for the bacteria during the colonization and the invasion of the bacteria in the host (Santos et al., 1999 and Zhu et al., 2007). Furthermore, Lipases have been considered to be important for bacterial nutrition and also play role as virulence factors by interacting with human leukocytes or by affecting several immune system functions through free fatty acids generated by lipolytic activity. Extracellular lipases secreted by Aeromonas spp. actively participate in the alteration of the host plasma membrane and thus increase the severity of infection (Pemberton et al., 1997).

Nevertheless, proteolytic and lioplytic properties of the Aeromonads in this study may cause bitterness, rancidity and other defects in milk and milk products. Therefore, good hygiene masseurs and strict eradication programs must be applied in dairy plant to produce milk and milk products save for human consumption and of good keeping quality.

Results in Table 4 revealed that, all the tested Aeromonas hydrophila, Aeromonas caviae and Aeromonas sobria organisms had $100 \%$ psychrotrophic properties. Lower results were estimated by Ahmed et al. (2014). The psychrotrophic properties of Aeromonads are aiding factors for survival and multiplication of the organisms in foods even at refrigerator temperature consequence health risks to consumers.

Table 4 showed that, all the tested Aeromonas hydrophila, Aeromonas caviae and Aeromonas sobria had $100 \% \beta$-haemolytic activities. Similar results were estimated by Subashkumar et al. (2006); AlFathawy and Al-Ammar (2013); Joseph et al. (2013); Taj-Aldeen et al. (2014); Al-Oqaili et al. (2016) and Simon et al. (2016). On the other hand, lower results were revealed by Majeed (2011); Manna et al. (2013); Amsaveni et al. (2014); Mansour et al. (2014) and Sharma et al. (2015).

Haemolytic activity is an index of pathogenicity and the relationship between the production of haemolysin and the enterotoxigenicity in Aeromonas spp. well documented (Obi et al., 2007). Nevertheless, all the isolated Aeromonads in this study were haemolytic on blood agar indicating their pathogenic nature and had potential public health significance in food of animal origin. Therefore it is concluded that, haemolytic activity on blood agar is simpler and an easier way than PCR assay for detection Aeromonads pathogenicity and also economical to use especially for developing countries.

The illustrated results in Table 5 and Photograph 1 revealed that, the incidences of aerA and $a h h 1$ genes in the tested Aeromonas hydrophila were 66.67 and
$77.78 \%$, respectively. Similar incidence was detected by Al-Fathawy and Al-Ammar (2013), whereas lower result was estimated by Yousr et al. (2007). In contrary, higher incidences were recorded by Rather et al. (2014) and Simon et al. (2016). The aerA and ahh 1 genes are cytotoxic and these two toxins contribute to development of severe diarrhoea in humans because of their synergistic effects (Guerra et al., 2007).

From Photograph 1 it is clear that, the strain of Aeromonas hydrophila in Lane 5 had neither aerA gene nor ahh 1 gene while it exhibited haemolytic activity on blood agar (Table 4). Therefore one can easily conclude that, haemolytic activity of Aeromonas hydrophila may be expressed by genes other than aerA and $a h h 1$ genes and this observation need further investigations.

The tabulated results in Table 6 showed that, all the tested Aeromonas hydrophila, Aeromonas caviae and Aeromonas sobria organisms exhibited $100 \%$ resistance towards Ampicillin, Amoxicillin and Erythromycin antibiotics. Similar results were revealed by Kannan et al. (2001); Majeed et al. (2011); Enany et al. (2013); Furmank-Blaszk (2014) and Sharma et al. (2015). The tested strains of Aeromonas hydrophila, Aeromonas caviae and Aeromonas sobria exhibited sensitivity to Kanamycin in percentages of 22.22, 40 and $75 \%$, respectively. Similar results were obtained by Subashkumar et al. (2006) and Didugu et al. (2016).

The isolated Aeromonas hydrophila, Aeromonas caviae and Aeromonas sobria organisms were sensitive towards Ceftriaxon in percentages of 55.56, 40 and $75 \%$, respectively (Table 6). Similar results were observed by Ragunathan et al. (2012) and Eidet al. (2013). For Tetracycline, the Aeromonas hydrophila, Aeromonas caviae and Aeromonas sobria organisms exhibited 44.44, 50 and 25\% sensitivity, respectively (Table 6) and these results simulated what obtained by Kaskhedikar and Chhabra (2010). While for Trimethoprim-Sulfamethoxazole, the tested organisms of Aeromonas hydrophila, Aeromonas caviae and Aeromonas sobria showed sensitivity percentages of $0.0,20$ and $50 \%$, respectively and these were lower than what detected by Aboulhamd (2010). Concerning Ciprofloxacin, all the tested Aeromonas hydrophila, Aeromonas caviae and Aeromonas sobria strains were sensitive in percentage of $100 \%$ and theses results go parallel with what estimated by Castro-Escarpulli et al. (2003); Yucel and Citak (2003); Guerra et al. (2007) and Kaskhedikar and Chhabra (2010).

The problem of Aeromonads resistance towards multiple antibiotics causes an increase in the risk of treatment failure and cost for antimicrobial therapy and hospitalization, while the range of therapeutic options decreases (Wen-Chien et al., 1998). 
Moreover, the emergence of pathogenic bacteria resistant to most, if not all, currently available antimicrobial agents has become a critical problem in modern medicine, particularly because of the concomitant increase in immune-suppressed patients.

\section{CONCLUSION}

This study revealed that, raw milk, kareish cheese and ice cream that retailed in Assiut city, are largely contaminated with Aeromonads microorganisms. The isolated Aeromonas hydrophila, Aeromonas caviae and Aeromonas sobria exhibited virulence properties on the bases of proteolytic, lioplytic, psychrotrophic and haemolytic activities and in addition to the presence of aerA and ahh 1 genes in Aeromonas hydrophila. Resistance of the recovered Aeromonads towards different varieties of antibiotics was observed and Ciprofloxacin was the most efficient antibiotic against Aeromonas species. Good hygienic control measures must be applied in dairy farms in addition to the use of raw milk of good bacteriological quality before manufacturing of different varieties of milk products.

Dedication: To the soul of Dr. N.H. Makar, Senior Researcher, Bacteriology Department, Animal Health Research Institute, Assiut Lab., who died before accomplishing this work.

\section{REFERENCES}

A.P.H.A. (2001): Compendium of Methods for the Microbiological Examination of Foods. $4^{\text {th }} \mathrm{Ed}$. American Public Heath Association, Washington, DC, USA

Abdel-Raouf, A.E. and Naima, F. (2011): Yersinia enterocolitica and Aeromonas hydrophila in clinical, food and environmental samples in Gaza. J. Al-Azhar Univ. Gaza, 13: 69-82.

Aboulhamd, A. (2010): Genetic diversity and antimicrobial susceptibility of motile aquatic Aeromonads. Int. J. Chem. Eng. Applications, 1 (1): 90-95.

Agarwal, R.K.; Kapoor, K.N.; Kumar, A. and Bhilegaonkar, K.N. (2000): Aeromonads in foods of animal origin. Indian J. Animal Sci., 70 (9): 942-943.

Ahmed, Nagwa, I.; Abdel-Aal, S.F.; Ayoub, Madeha, A. and El Sayed, M.S. (2014): Enumeration and characterization of Aeromonassp. isolated from milk and some dairy products in Sharkia Governorate Egypt. Alexandria J. Vet. Sci., 40: 52-64.

Akan, M.; Diker, K.S.; Kocak, C.; Yildirim, M. and Bozkurt, S. (1996): Isolation of moltile Aeromonads from raw milk. Gida, 21(5): 383386.

Al-Ashmawy, Maha, A. (2000): Public health importance of Aeromonas organisms in some dairy products. M. V. Sc. Thesis, Fac. Vet. Med., Suez Canal Univ., Egypt.

Al-Fathawy, H. and Al-Ammar, M. (2013): Study of some virulence factors of Aeromonas hydrophila isolated from clinical samples (Iraq). Int. J. Sci. Eng. Invest., 2 (21): 114122.

Al-Oqaili, Rasha, M.; Sachit, S.M. and Shieer, A.M. (2016): Putative virulence factor and antimicrobial susceptibility of locally bacteria Aeromonas hydrophila isolated from surface Tigres river in Baghdad, Iraq. World J. Pharm. Res., 5 (4): 163-171.

Alrazakkazal, A. and Abdullah, Fawziah, A. (2016): PCR based detection of gram negative psychrotrophic bacteria in cow's raw milk. Basrah J. Vet. Res., 15 (1): 161-180.

Amer, I.H.; Abdel-Aal, S.F. and Tolba, M.H. (2008): Presence and activity of psychrotrophic bacteria in raw cow's milk and some dairy products. Proc. $9^{\text {th }}$ Vet. Med. Conf., Zagazig Univ., Egypt, pp. 61-77.

Amsaveni, R.; Sureshkumar, M. and Vivekanandhan, G. (2014): Screening of pathogenic Aeromonas species from marketed fish samples. Int. J. Pharmacy Pharmaceutical Sci., 6 (8): 148-150.

Aslani, M.M. and Alikhani, M.Y. (2004): The role of Aeromonas hydrophila in diarrhea. Iranian $\mathrm{J}$. Publ. Health, 33 (3): 54-59.

Avolio, M.; La Spisa, C.; Moscariello, F.; De Rosa, R. and Camporese, A. (2009): Aeromonas hydrophila ecthyma gangrenosum without bacteraemia in a diabetic man: the first case report in Italy. Le Infezioni Medicina, 3: 184187.

Castro-Escarpulli, G.; Figueras, M.; AguileraArreola, G.; Soler, L.; Fernández-Rendón, E.; Aparicio, G.; Guarro, J. and Chacón, M. (2003): Characterisation of Aeromonas species isolated from frozen fish intended for human consumption in Mexico. Int. J. Food Microbiol., 84: 41-49.

Chang, Y.C.; Wang, J.Y.; Selvam, A.; Kao, S.C.; Yan, S.S. and Shih, D.Y. (2008): Multiplex PCR detection of enterotoxin genes in Aeromonas species from suspect food samples in northern Taiwan. J. Food Protec., 71 (10): 2094-2099.

Chou, S.; Tsai, C.; Kau, S.; Kau, H. and Hsu, W. (2004): Aeromonas hydrophila orbital cellulitis in a patient with myelodysplastic syndrome. J. Chinese Med. Assoc., 67 (1): 5153.

CLSI "Clinical and Laboratory Standards Institute" (2011): Performance standards for antimicrobial susceptibility testing: Twenty First Informational Supplement M100S21. Wayne, PA.

Didugu, H.; Krishnaiah, N.; Madhava, R. and Ramanipushpa, R. (2016): Antibiogram of 
Aeromonas species isolated from livestock products. Int. J. Sci. Technol., 5 (2): 475-478.

Easow, J. and Tuladhar, R. (2007): Aeromonas hydrophila wound infection following a tiger bite in Nepal. Southeast Asian J. Trop. Med. Public Health, 38 (5):867-870.

Effat, B.A.; Hosny, I.M. and Dabiza, N.M. (2000): Occurrence of Aeromonas hydrophila and its growth in Egyptian soft cheese. Egyptian J. Dairy Sci.,28 (1): 1-12.

Eid, HE.M.; Shalaby, Amany, M. and Soltan, Samar, E. (2013): Incidence of Aeromonas species isolated from different food sources and water. Suez Canal Vet. Med. J., 18 (1): 37-44.

El-Leboudy, Ahlam, A.; Amer, A. and Abdel-Mohsen, Sarah (2014): Detection of some pathogenic organisms from dairy farm milk. Alexandria J. Vet. Sci., 44: 111-118.

El-Shorbagy, I.M. and Al-Ganzoury, H.H. (2002): Incidence of Aeromonas species in raw milk and yoghurt in Zagazig city. J. Egyptian Vet. Med. Assoc., 62 (4): 229-233.

El-Taib, Khalilia, A. and Mohamed, Sahar, R. (2010): Bacteriological study on Aeromonas hydrophila in some food. J. Egyptian Vet. Med. Assoc., 70 (3): 377-386.

Enany, M.E.; Shalaby, A.M.; Shabanaa, I.I.; ELGammal, A.M. and Hassan, Marwa E. (2013): Characterization of Aeromonas hydrophila complex isolated from foods of animal origin. Suez Canal Vet. Med. J., 18 (2): 165-176.

Furmank-Blaszk, B. (2014): Phenotypic and molecular characteristics of an Aeromonas hydrophila strain isolated from the River Nile. Microbiol. Res., 169: 547-552.

Geetha, V. and Michael, A. (2015): Molecular identification and characterization of Aeromonas hydrophila isolated from infected fish rohu. Indian J. Appl. Res., 5 (7): 657-659.

Ghenghesh, K.S.; Ahmed, S.F.; El-Khalek, R.A.; AlGendy, A. and Klena, J. (2008): Aeromonasassociated infections in developing countries. J. Infect. Develop. Count., 2:81-98.

Guerra, I.M.; Fadanella, R.; Figuerió, M.; Schreiner, F.; Dalmare, A.p.; Wallheim, C.; Costa, S.O. and Echeverrigaray, S. (2007): Aeromonas associated diarrhoeal disease in south Brazil: prevalence, virulence factors and antimicrobial resistance. Brazilian J. Microbiol., 38: 638643.

Harrigan, W.F. (1998): Laboratory methods in food microbiology. $3^{\text {rd }}$ Ed. Academic, London, pp 202-245.

Janda, J.M. and Duffey, P.S. (1988): Mesophilic Aeromonas in human disease: Current taxonomy laboratory identification and infectious diseases spectrum. Rev. Infect. Dis., 10 (5): 980-997.

Joseph, A.V.; Sasidharan, R.S.; Nair, H.P. and Bhat, S.G. (2013): Occurrence of potential pathogenic Aeromonas species in tropical seafood, aquafarms and mangroves off Cochin coast in South India. Vet. World, 6 (6): 300306.

Kannan, S.; Chaltopadhay, U.; Pal, D.; Shimada, T.; Takeda, Y.; Bhattacharya, S. and Ananthanarayanan, P. (2001): Isolation and identification of Aeromonas from patients with acute diarrhoea in Kolkata, India. Indian J. Med. Microbiol., 19 (4): 190-192.

Kao, H.; Huang, Y. and Lin, T. (2003): Fatal bacteremic pneumonia caused by Aeromonas hydrophila in a previously healthy child. $\mathrm{J}$. Microbiol. Immunol. Infect., 36: 209-211.

Kaskhedikar, M. and Chhabra, D. (2010): Multiple drug resistance in Aeromonas hydrophila isolates of fish. Vet. World, 3 (2): 76-77.

Korashy, Nahla, T. (2006): A study on mesophilic Aeromonas in milk and some milk products in Port Said City. J. Appl. Sci. Res., 2 (11): 10371041 .

Lampert, L.M. (1975): Modern Dairy Products. $3^{\text {rd }}$ Ed., Chemical Pub. Co., Inc., New York.

Liu, B.; Kung, C.; Lee, W.; Liu, C. and Chung, K. (2005): Acute diarrheoa followed by fatal Aeromonas hydrophila infection of soft tissue in a cirrhotic patient. J. Taiwan Emerg. Med., 7 (3):171-176.

Majeed, Hadeel, A. (2011): Characterization of Aeromonas hydrophila isolated from patients with diarrhea. J. Kerbala Univ., 9 (3): 33-42.

Manna, S.K.; Maurye, P.; Dutta, C. and Samanta, G. (2013): Occurrence and virulence characteristics of Aeromonas species in meat, milk and fish in India. J. Food Safety, 33: 461469.

Mansour, A.; Zaki, Hoda, M.; Hassan, Nabila, A. and El-Nashar, Nihad, A. (2014): Phenotyping, virulence characteristics of Aeromonas species and the effects of essential plant oils as antimicrobial agents against pathogenic isolates from different sources. Am. J. Infec. Dis., 10 (1): 21-35.

Marchandin, H.; Godreuil, S.; Darbas, H.; JeanPierre, H.; Jumas-Bilak, E.; Chanal, C. and Bonnet, $R$. (2003): Extended-spectrum $\beta$ lactamase TEM-24 in an Aeromonas clinical strain: acquisition from the prevalent Enterobacter aerogenes clone in France. Antimicrob. Agents Chemother., 47: 39943995.

Melas, D.S.; Papageorgiou, D.K.; Mantis, A.I. (1999): Enumeration and confirmation of Aeromonas hydrophila, Aeromonas caviae, and Aeromonas sobria isolated from raw milk and other milk products in Northern Greece. J. Food Protec., 62 (5): 463-466.

Motlagh, A.M.; Johnson, M.C. and Ray, B. (1991): Viability loss of food borne pathogens by starter culture metabolites. J. Food Prot., 54 (11): 837-878. 
Nazem, A.M.; Amer, A.A. and Abdel-Hady, Soukayna (2010): Prevalence of some food poisoning microorganisms in some dairy products. Alexandria J. Vet Sci., 30 (1): 1-6.

Obi, C.L.; Ramalivhana, J.; Samie, A. and Igumbor, E.O. (2007): Prevalence, pathogenesis, antibiotic susceptibility profiles, and in-vitro activity of selected medicinal plants against Aeromonas isolates from stool samples of patients in the Venda region of South Africa. J. Health Popul. Nutr., 25: 428-435.

Odeyemi, O.A. and Ahmad, A. (2014): Anti-biogram and resistogram profiling of Aeromonas species isolated from Malaysian coastal seawater. Pollut. Res., 33: 487-492.

Oliver, S.P.; Jayarao, B.M. and Almeida, R.A. (2005): Foodborne pathogens, mastitis, milk quality, and dairy food safety. The University of Tennessee, Knoxville.NMC Annual Meeting Proceedings.3-27.

Palumbo, S.; Abcyta, C. and Stelma, G. (2001): Aeromonas, Arcobacter and Plesiomonas. In: "Compendium of Methods for the Microbiological Examination of Foods". (4 ${ }^{\text {th }}$ Ed), American Public Health Association, Washington, DC, USA

Pemberton, J.M.; Kidd, S.P. and Schmidt, R. (1997): Secreted enzymes of Aeromonas. FEMS Microbiol. Lett., 152: 1-10.

Ragunathan, L.; Kavitha, K.; Raveendran, $V_{\text {.; }}$ Dhandapani, S.; Jaget, N. and Kannivelu, J. (2012): Aeromonas hydrophila urinary tract infection in pregnancy- Case report and literature review. J. Microbiol. Infec. Dis., 2 (1): 26-28.

Rather, M.R.; Willayat, M.M.; Wani, S.A.; Munshi, Z.H. and Hussain, S.A. (2014): A multiplex PCR for detection of enterotoxin genes in Aeromonas species isolated from foods of animal origin and human diarrhoeal samples. J. Appl. Microbiol., 117: 1721-1729.

Santos, J.A.; Gonzalez, C.J.; Otero, A. and GarciaLopez, M.L. (1999): Hemolytic activity and siderophore production in different Aeromonas species isolated from fish. Appl. Environ. Microbiol., 65: 5612-5614.

Scoaris, D.; Colacite, J.; Nakamura, C.; UedaNakamura, T.; Filho, B. and Filho, B. (2008): Virulence and antibiotic susceptibility of Aeromonas species isolated from drinking water. Antonie Leeuwenhoek, 93:111-122.

Seker, E.; Ozenc, E.; Konak, S.; Pamuk, S. and Kuyucuoglu, Y. (2015): Occurrence, hemolytic toxins and antimicrobial resistance of Aeromonas hydrophila strains from dairy cow and Anatolian water buffalo quarter milk samples in Turkey. Acta Scientiae Veterinariae, 43: 1299.

Shah, D.; Shringi, S.; Besser, T. and Call, D. (2009): Molecular detection of foodborne pathogens,
Boca Raton: CRC Press, In Liu, D. (Ed). Taylor \& Francis group, Florida, USA, Pp. 369-389.

Sharef, N.; Ghenghesh, K.S.; Abognah, Y.S.; Gnan, S.O. and Rahouma, A. (2006): Bacteriological quality of ice cream in Tripoli-Libya. Food Control, 17: 637-641.

Sharma, I. and Kumar, A. (2011): Occurrence of enterotoxigenic Aeromonas species in foods of animal origin in North East India. Eur. Rev. Med. Pharmacol. Sci., 15: 883-887.

Sharma, I. and Kumar, A. (2012): Distribution of virulence genes in A. hydrophila and A. sobria in L. rohita (Rohu Fish) in N.E. India. Res. J., 7 (4): 205-207.

Sharma, I.; Rabha, D.; Das, S. and Ningombam, D. (2015): Hemolytic activity and antibiotic resistance of Aeromonas species isolated from marketed fish. Eur. J. Pharmaceutical Med. Res., 2 (4): 304-312.

Simon, S.; Lalitha, K. and Joseph, T. (2016): Virulence properties of Aeromonas species from modified-atmosphere- and vacuumpacked milk fish (Chanoschanos Forsskal, 1775). Ann. Microbiol., 66: 1109-1115.

Singh, V.; Chaudhary, D.; Mani, I.; Somvanshi, P.; Rathore, G. and Sood, N. (2010): Molecular identification and codon optimization analysis of major virulence encoding genes of Aeromonas hydrophila. African J. Microbiol. Res., 4 (10): 952-957.

Stratev, D.; Gurova, E.; Vashin, I. and Daskalov, $H$. (2016): Multiplex PCR detection of heamolysin genes in $\beta$-heamolytic Aeromonas hydrophila strains isolated from fish and fish products. Bulgarian J. Agricul. Sci., 22 (2): 308-314.

Subashkumar, R.; Thayumanavan, T. and Thilagavathy, C. (2006): Typing of haemolytic and antibiotic resistant Aeromonas hydrophila isolated from raw milk of Coimbatore, South India. Int. J. Dairy Sci., 1 (1): 70-83.

Swift, S.; Lynch, M.J.; Fish, L.; Kirke, D.F.; Tomás, J.M.; Stewart, G.S. and Williams, P. (1999): Quorum sensing-dependent regulation and blockade of exoprotease production in Aeromonas hydrophila. Infect. Immun., 67: 5192-5199.

Taj-Aldeen, Wejdan, R.; Al-Rubaiae, Abeer, F.; AlBermani, Oruba, K. and Naji, Noor, S. (2014): PCR detection of putative hemolysin and aerolysin genes in an Aeromonas hydrophila isolates from diarrhea in Babylon province. $\mathbf{J}$. Natural Sci. Res., 4 (11): 41-47.

Talan, A.; Altunbaş, H.; Kolağası, O.; Seyman, D. and Karayalçın, $\ddot{U}$. (2014): Diabetic foot due to Aeromonas hydrophila and Pseudomonas oryzihabitans: A case report. Turkish J. Endocrinol. Metabol., 18: 100-102. 
Tsai, C.; Ho, Y. and Wang, L. (2005): Aeromonas hydrophila bacteremia presenting as epidural abscess in a cirrhotic patient-A Case report. Tzu. Chinese Med. J., 17: 429-432.

Van Gravenitz, A. (2007): The role of Aeromonas in diarrhea: a review. Infection, 35: 59-64.

Vila, J.; Marco, F.; Soler, M.; Chacón, M. and Figueras, M.J. (2002): In vitro antimicrobial susceptibility of clinical isolates of Aeromonas caviae, Aeromonas hydrophila, and Aeromonas veronii biotype sobria. J. Antimicrob. Chemoth., 49: 701-702.

Wang, G.; Clark, C.; Liu, C.; Pucknell, K.; Munro, C.; Kruk, T.; Caldeira, R.; Woodward, D. and Rodgers, F. (2003): Detection and characterization of the hemolysin genes in Aeromonas hydrophila and Aeromonas sobria by multiplex PCR. J. Clin. Microbiol., 41: 1048-1054.

Wen-Chien, K.; Hsiu-Mei, W.; Tsung-Chain, C.; Jing-Jou, Y. and Jiunn-Jong, W. (1998): Inducible $\beta$-lactam resistance in Aeromonas hydrophila: therapeutic challenge for antimicrobial therapy. J. Clin. Microbiol., 36 (11): 3188-3192.

Yousr, A.H.; Napis, S.; Rusul, G. and Son, R. (2007): Detection of aerolysin and hemolysin genes in Aeromonas species isolated from environmental and shellfish sources by polymerase chain reaction. ASEAN Food J., 14 (2): 115-122.

Yucel, N. and Citak, S. (2003): The occurrence, hemolytic activity and antibiotic susceptibility of motile Aeromonas species isolated from meat and milk samples in Turkey. J. Food Safely, 23: 189-200.

Yucel, N.; Erdem, B. and Kaya, D. (2005): Some virulence properties and characterization of motile Aeromonas species from milk and white cheese. Int. J. Dairy Tech., 58 (2):106110.

Yumoto, T.; Ichiba, S.; Umei, N.; Morisada, S.; Tsukahara, K.; Sato, K.; Ugawa, T. and Ujike, $Y$. (2014): Septic shock due to Aeromonas hydrophila bacteremia in a patient with alcoholic liver cirrhosis. a case report. J. Med. Case Reports, 8: 402.

Zeinhom, M.A. and Abdel-Latef, Gihan, K. (2014): Public health risk of some milk borne pathogens. Beni-Suef Univ. J. Basic Appl. Sci., 3(3): 209-215.

Zhu, D.L.; Li, A.H.; Wang, J.G.; Li, M.; Cai, T.Z. and $H u, J$. (2007): The correlation between the distribution pattern of virulence genes and the virulence of Aeromonas hydrophila strains. Front. Biol. China, 2 (2): 176-179.

\title{
الكشف عن الايروموناس هيدروفيلا في اللبن الخام وبعض منتجات الألبان مع الإشارة إلي خطورتها علي الصحة العامة وبعة منامة أنسي أدبي صادق ، نبيل حبيب مقار ، سعد محروس فهيم البرياوي
}

Email: onsi_2000@yahoo.com Assiut University web-site: www.aun.edu.eg

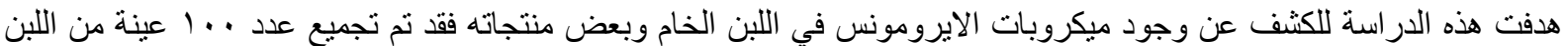

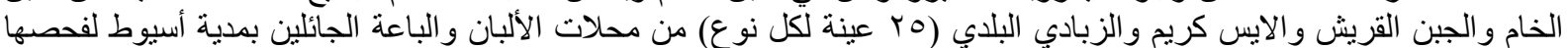

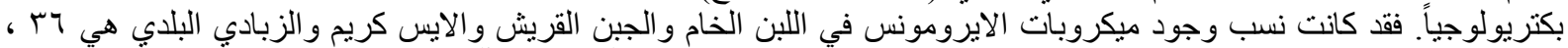

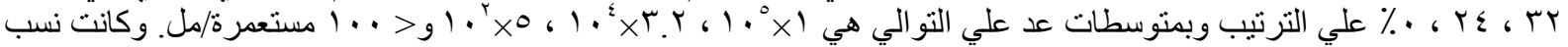

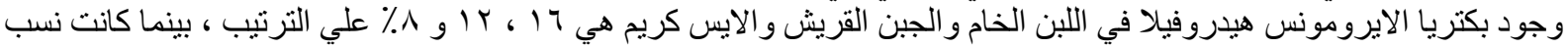

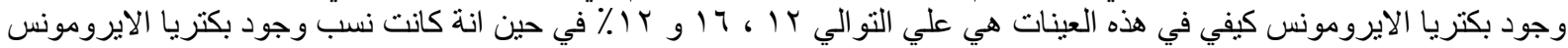

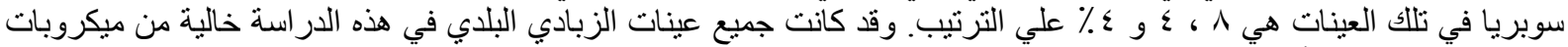

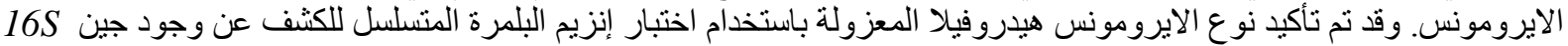

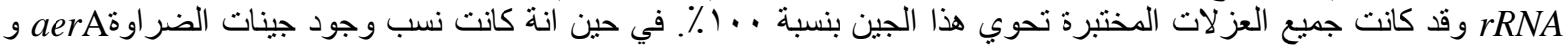

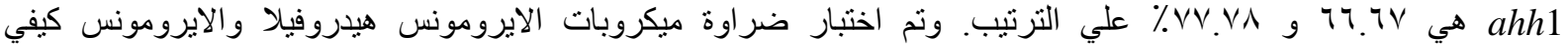

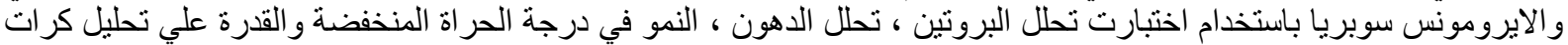

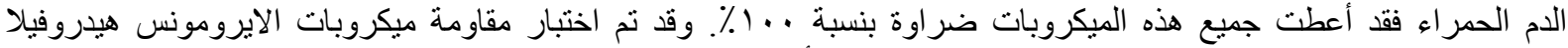

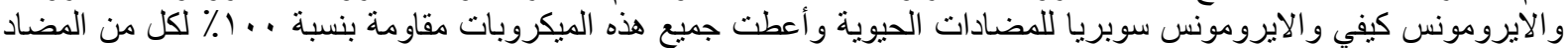

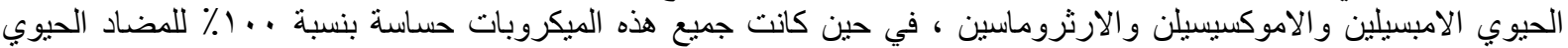

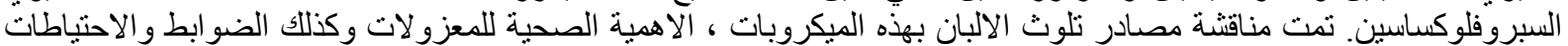
الو اجب إتباعها للحد من تلوث الالبان ومنتجاتها بها.
\end{abstract}

